\title{
Bakke: A Constitutional Analysis $\dagger$
}

\author{
Robert G. Dixon, Jr.ł
}

In Regents of the University of California v. Bakke, ${ }^{1}$ the Justices discussed much and ultimately decided little, thus mirroring the popular tensions on the problem of race preferences and scarce resources. Yet the case does have significant doctrinal importance at this stage of our constitutional evolution on race matters. Justice Powell's opinion seems to suggest a new institutional-focused theory for justifying some consideration of race, beyond the familiar remedial context, when relevant to the enterprise. Underlying all of the opinions on the nierits is the obvious need to clarify our thinking on the concept of "discrimination" itself, and the emerging question of individual rights versus group rights in our constitutional order.

The actual "ruling" in Bakke, stemming only from Justice Powell's tiebreaking opinion, that race inay be $a$ factor but not the factor in the admissions criteria of state universities, has acquired wide pragmatic appeal. It was perhaps the grandest finesse of a searing legal issue in Supreine Court history, but it rests neither on a Supreme Court consensus nor on a clear doctrinal foundation. And yet, despite the dangers of "all deliberate speed" that we supposedly learned from Brown v. Board of Education, ${ }^{2}$ the Bakke-type problem may be one where a bit of temporizing is not inappropriate, if we can keep it from getting out of hand.

At our symposium at Washington Umiversity last November on "Race Preferences and Scarce Resources,"3 Erwin Griswold observed that the full dimension of the Bakke problem, given the race history

$\dagger$ Copyright 1979, Robert G. Dixon, Jr. This Article derives from a paper presented at the annual meeting of the Association of American Law Schools plenary session on the Bakke case in Chicago on January 4, 1979, and will be incorporated in a book, The Supreme Court and Eguality, in preparation for Cornell University Press. The author gratefully acknowledges the assistance of Valerie Staulcup, a second-year law student at Washington University.

$\ddagger$ Daniel Noyes Kirby Professor of Law, Washington University. A.B. 1943, Ph.D. 1947, Syracuse University; J.D. 1956 George Washington University. Assistant Attorney General in charge of the Office of Legal Counsel, United States Department of Justice, 1973-74.

1. 98 S. Ct. 2733 (1978).

2. 349 U.S. 294 (1955) (Brown In).

3. The symposium was the third in a series of nine symposia on "The Quest for Equality" presented by the Washington University School of Law with the aid of the Deer Creek Foundation. Participating with former Solicitor General Erwin N. Griswold were Assistant Attorney General Drew S. Days III of the Civil Rights Division of the Department of Justice and Professor 
and current racial realities of America, may be more philosophical and moral than legal. Nathan Glazer, who also was present, would add political to the calculus; and both Professors Griswold and Glazer doubted that a complete solution could be found in constitutional law.

With full sympathy for this view I do feel compelled to stress that the issue has been taken into our constitutional system; the mootness ploy of DeFunis is over, ${ }^{4}$ and use of the political question doctrine was never considered nor would it have been credible. Once taken into our constitutional law system, the dialogue takes on a new seriousness. It is, therefore, critically important that we get the questions right and the answers right, because constitutional law is written in concrete and is not easily washed out by rain or tears.

\section{The Fragility of BAKKe}

In Bakke, Justice Stevens, writing for a bloc of four justices, did not reach the constitutional issue, but found the two-track admissions policy at the Davis medical school illegal under the nondiscrimination principle of Title VI of the Civil Rights Act of $1964^{5}$ because it operated to exclude Allan Bakke, whose test scores averaged at approxinately the 90th percentile, while admitting Asian Americans, Chicanos, and blacks, ${ }^{6}$ whose test scores averaged at the 30 th percentile. ${ }^{7}$ Justice Stevens stressed both the language of the Act-no "dis-

Nathan Glazer of the Department of Sociology of Harvard University. The present writer is the chairman and moderator of the series. The symposia will be published in 1979 WASH. U.L.Q. I.

4. DeFunis v. Odegaard, 416 U.S. 312 (1974).

5. 42 U.S.C. $\$ 2000 \mathrm{~d}(1976)$.

6. Technically the Davis medical school considered a fourth group-American Indians (Native Americans) -in its sccond track admissions proccdure, Regents of the Univ. of Cal. $v$. Bakke, $98 \mathrm{~S}$. Ct. at 2740 , but the record shows no actual examples. Id. at 2741 n.6.

7. Id. at 2742 n.7. The percentile figures mentioned in the text relate to performance on the national Medical College Admissions Test in 1974, the last year for which the University presented data. In that year Bakke's 90 th percentile average also substantially exceeded the 73rd percentile average of the regular admittees. The overall grade point averages for 1974 on a 4.0 scale also showed the following disparities: Bakke, 3.5I; average of regular admittees, 3.29; average of special admittees, 2.62. Id.

Bakke's admissions difficulties seemed to center on one man, Dr. George H. Lowrey, Chairman of the Admissions Committee and Associate Dean of the medical school. Dr. Lowrey participated in the interview segment of the admissions process and was not bound by the high interview ratings Bakke received from others on the committee. See oral argument in Bakke v. Regents of the Univ. of Cal., 18 Cal. 3d 34, 553 P.2d 1152, 132 Cal. Rptr. 680 (1976), rev'd, 98 S. Ct. 2733 (1978), reprinted in 2 ALLAN BAKKE VERSUS REGENTS OF THE UNIVERSITY OF CALIFORNIA 42-43 (A. Slocum ed. 1978). During oral argument, Justice Mosk remarked that Bakke had received "very high marks" from other evaluators until he came to Dr. Lowrey, "more than half" of whose report on Bakke was about "Bakke's views" on preferential admissions. Id. at 23-24 (referring to Bakke's second application year, 1974).

As summarized in Justice Powell's opinion in the Supreme Court of the United States, Dr. Theodore H. West, in 1973, had considered Bakke "a very desirable applicant," but despite a 
crimination" against any "person" in any federally aided program-and the congressional history, exemphified by statements such as the late Senator Hubert Humphrey's ringing declaration that the goal was to "treat Americans as Americans, not as fat ones, short ones, tall ones, brown ones, green ones, yellow ones, or white ones, but as Americans."

Justices Brennan, White, Marshall, and Blackmun would have updated the Civil Rights Act without benefit of clearcut congressional guidance and permitted the Davis quota system. On this statutory debate let me rephrase the issue: What should the Court do when an original statutory consensus--a broad nondiscrimination consensus as in the 1964 Civil Rights Act-becomes overlaid by inconsistent practices of race preference and affinnative action supported by federal civil rights agencies, lower courts, and even some seemingly inconsistent subsequent congressional action? ${ }^{9}$

Justice Powell, writing only for himself, said that the statute should be read to mean whatever the Constitution meant, which is a heady principle of delegation of legislative power. Thus, the Constitution was reached, where ultimately on the race preference issue Justice Powell said that it permitted "some" consideration of race and the Brennan group said that it permitted "much." Adding Justice Powell's "some" to Justice Stevens "none," the Davis plan failed because it was

"strong" benchmark score of 468, Bakke was not admitted. His application had come late in the year, and no regular admission process applicants with scores below 470 were accepted in 1973 after Bakke's application arrived. In 1974, Bakke's application arrived early, but his "faculty mterviewer was, by coincidence, the same Dr. Lowrey to whou he had written in protest of the special admission program" after his rejection in 1973. Dr. Lowrey gave Bakke the "lowest of his six ratings." In neither 1973 nor 1974 did Lowrey exercise his discretion to place Bakke on the waiting hist. Regents of the Univ. of Cal. v. Bakke, $98 \mathrm{~S}$. Ct. at 2741.

This sequence of events prompted Professor Alan Dershowitz to remark, in reference to Lowrey, that "Alan [sic] Bakke himself nay have been victimized by an unconscionable-and perhaps unconstitutional-exercise of discretion." Dershowitz, The Bakke Decision: A Triumph of Ambiguity Over Clarity, Boston Globe, July 7, 1978, at 17, cols. 2-5. The University, however, did not concede graciously. Newsweek concluded its story on the Bakke case as follows: "But his personal victory could prove to be something of a stigma. As Dr. Morton Levitt, Associate Dean of the medical school, says: 'He will never not be Allan Bakke,' the man who was able to become a doctor by order of the U.S. Supreme Court." Dr. Bakke?, NewsweEk, July 10, 1978, at 24.

8. 110 CONG. REC. 5866 (1964) (remarks of Sen. Humphrey, the Senate floor manager for the Act).

9. See, e.g., Public Works Compensation Act of 1977, 42 U.S.C.A. $\$ 6705(f)(2)$ (West Supp. 1978) (amending 42 U.S.C. $\$ 6705$ (1976)), which placed a temporary condition on federal grants for local public works that $10 \%$ of each grant be set aside for minority business enterprises. The pre-Bakke split ainong the lower federal courts on the constitutionality of the $10 \%$ set-aside provision has continued after Bakke: Fullilove v. Kreps, 584 F.2d 600 (2d Cir. 1978) (constitutional); Ohio Contractors Ass'n v. Economic Dev. Adininistration, 580 F.2d 213 (6th Cir. 1978) (constitutional); Montana Contractors Ass'n v. Secretary of Commerce, 460 F. Supp. 1174 (D. Mont. 1978) (unconstitutional); Associated Gen. Contractors v. Secretary of Commerce, 459 F. Supp. 766 (C. D. Cal. 1978) (unconstitutional). 
a much too explicit racial quota. ${ }^{10}$

The duration of Justice Powell's position as the rule of the case (if we can even call it that), ${ }^{11}$ with all its pragmatic attractiveness to many commentators, is subject to several variables. There is first the possibility that in some future case, with no civil rights act in the picture, one of the Stevens group may join the Brennan group and as a matter of constitutional law embrace a broad, open-ended concept of societal discrimination. Second, even in a future Title Vl case, one or all of the Stevens group might take the broader view of Title VI, seemingly endorsed by the other five justices in Bakke, that it proscribes only those racial classifications that violate the Constitution. Third, there is the question of the tiining and nature of a President Carter appointment to the Supreme Court. Fourth, the institution seeking to impose a Davistype racially separate and unequal quota system might make justifying "findings" of discrimmation and present the quota as a remedial meas-

10. Query whether Bakke might have been decided the other way in both the Supreme Court of California, Bakke v. Regents of the Univ. of Cal., 18 Cal. 3d 34, 553 P.2d 1152, 132 Cal. Rptr. 680 (1976), rev'd, 98 S. Ct. 2733 (1978), and the Supreme Court of the United States, which affirmed the state court's order admitting Allan Bakke, $98 \mathrm{~S}$. Ct. at 2739 , if there had not been such a wide disparity in the test results and grade point averages between Bakke and the minority admittees? See the figures cited in note 7 supra.

A substantial portion of the oral argument in the California Supreme Court was consumed by questions from the bench, directed primarily at Mr. Reidhaar, counsel for the Regents, probing the qualifications of the minority admittees. Justice Mosk, who subsequently wrote the majority opinion for six of the seven justices, was concerned that "many" of the "preferential" admittees had a college grade point average as low as 2.1 , on a 4.0 scale, over the five year period for which data was presented. 2 Allan BakKe versus Regents of the UNIVERsity of CAlifornia, supra note 7, at 7. Questioning by Chief Justice Wright elicited the information that there was no "absolute bottom figure" for a minority admittee and it was "not inconceivable" (although "fairly unlikely") that the figure could go to "1.9 or 1.7." Id. at 21 . Asked whether all whites with averages above the normal minimum of 2.5 received interviews, the Regents' counsel said they "might or might not" be interviewed. Id. at 9-10.

At the end of oral argument Justice Sullivan observed that the Regents' counsel seemed to have "two definitions of the word "qualified." Id. at 48. All of this led Chief Justice Wright to characterize the Davis medical school's consideration of race as the only relevant nonacademic factor as "the lazy man's way out." Id. at 46-47.

Justice Tobriner, who ultimately filed the only dissent to the California court's order admitting Mr. Bakke, indicated that he saw no difference between a policy of seeking racial intermixture in the elementary and secondary schools during the period of compulsory attendance by rearranging the students already there, and a policy of seeking racial intermixture in medical schools by having a double standard admission policy. Id. at 33.

11. Justice Stevens, writing for Chief Justice Burger and Justices Stewart and Rehnquist, who with Powell yielded the necessary five votes to enjoin Davis to admit Bakke, looked at the state judgments being reviewed. He said that the question whether "race can ever be used as a factor" in admissions was not presented in the petition. Yet he went on to agree with the trial court that Title VI of the 1964 Civil Rights Act prohibited racially based exclusion of any person from participation in any federally assisted activity, and that Davis had violated the Act "by excluding Bakke from the medical school because of his race." $98 \mathrm{~S}$. Ct. at 2815. And he characterized the trial court's judgment as ordering "the University to consider Bakke's application for admission without regard to his race or the race of any other applicant." Id. at 2809. Looking at the same record, Justice Powell deemed "unreasonable" Justice Stevens' view that the "race as a factor" question was not at issuc in the appeal. Id. at $2738 \mathrm{n.}^{* *}$. 
ure. Both Powell and the Brennan group agreed on this possibility, subject to the caveat that it be a body witl authority to make such findings. ${ }^{12}$ A strongly limiting factor on this possibility, however, is that insofar as the findings would have to rest on admissions of past culpability, there is a strong disincentive for an institution to make thein. The institution would be opening itself to class suits for dannages or special equitable relief, for example, back pay, in the einployment field.

Fifth, suclı findings might be made by some other authorized governmental body. Botli Justice Powell and the Brennan group spoke generally of "judicial, legislative, or administrative" organs. Efforts in that direction will keep alive the controversy over manner of proof of the necessary "discriminatory imtent" in Constitution-based cases, ${ }^{13}$ and the breadtl of the "effects" test in statutory and executive order cases. ${ }^{14}$ Sixth, the simple option of rewriting the 1964 Civil Rights Act, on whicl Justice Stevens relied, im order to modify the personal nondiscrimination principle seems most unlikely. As civil libertarian attorney Joseph Rauh stated on the eve of the Bakke oral argument, "we can't win a fight in Congress to change Title VI our way," but he felt that his forces had the votes to prevent any deliberalizing of Title VI. ${ }^{15}$ (The history of the antibusing legislation-i.e., the congressional votes and not the ineffective outcome in the courts-testifies to the trutl of Rauh's statement.) These same political realities may make it unlikely that Congress can muster a majority vote for generalized "findings" of discrimination of the sort contemplated by Powell and the Brennan group.

12. Id. at 2758 (opinion of Powell, J.), 2787 n. 42 (Brennan, White, Marshall, and Blackmun, J.J., concurring in the judgment in part and dissenting).

13. See Village of Arlington Heights v. Metropolitan Hous. Dev. Corp., 429 U.S. 252 (1977); Washington v. Davis, 426 U.S. 229, 238-48 (1976).

14. See Washington v. Davis, 426 U.S. at 248-52, 255-56 (Stevens, J., concurring), 256-70 (Brennan, Marshall, J.J., dissenting); Metropolitan Housing Developinent Corp. v. Village of Arlington Heights, 558 F.2d 1283 (7th Cir. 1977) (Arlington Heights II on remand). Critical to intelligent discourse in this area is avoidance of use of the word "discriminatory," as in "discriminatory effect," when all that has been proven is absence of affirmative action to change traditional policies to promote racial intermixture. In such instances, which may encompass most of the statutory and executive order cases, the preferable term would be "nonproportional effect." The focus should be not on mislabeling "nonproportionality" as "discriminatory," but on deciding under what conditions mere "nonproportionality" should create an affirmative governmental duty to respond, inposed either by statute or by constitutional interpretation. In Arlington Heights II, such termmological confusion occurs in Judge Swygert's opinion, along with himts of an awareness that "discriminatory" by itself has become an ambiguous term. For a discussion of the earlier zoning cases, see Mandelker, Racial Discrimination and Exclusionary Zoning: A Perspective on Arlington Heights, 55 Texas L. Rev. 1217 (1977). See also Weber v. Kaiser Aluminim \& Chein. Corp., 563 F.2d 216, 224-27 (majority opimion), 229-34, 236-38 (dissenting opinion) (5th Cir. 1977), cert. granted, 47 U.S.L.W. 3401 (Dec. 11, 1978) (No. 78-435), for a discussion of both Title VII and Executive Order 11246 aspects of the "proof" issue.

15. Bakke Decision May Rely on Civil Rights Law, Wash. Post, Oct. 18, 1977, \& A, at 1, col 5. 
The attraction of the Powell compromise to many is that it sets forth neither a notion of strictly colorblind imdividualism nor a notion of large-scale reparations and race preferences based on the loose concept of societal discrimmation. But insofar as the compromise rests neither on clear doctrine nor Court consensus we are $\mathrm{m}$ more of a "bricks without straw" situation than ever before. The Bakke problem is far more complex than school desegregation or any issue heretofore encountered under the equal protection of the laws principle. Indeed, imsoluble might be a better word, but that word is not part of the American vocabulary. On the one hand, there is the plea froin inany blacks for reparations im the forn of a substantial approximation to ethnic proportionality in the allocation of scarce social goods. This plea necessarily includes a call to lower (but not entirely eliminate) conventional entry standards keyed to competitive tests. On the other hand, a policy of etlimic proportionality that qualifies a person's equality of opportunity has no foundation in our individual-rights focused constitutional tradition; ${ }^{16}$ no foundation in the traditional western concept of equal citizenship, a status keyed to personality and not to groups; ${ }^{17}$ and no foundation in the customary imbalanced etlimic patterns that we can observe in our own country and elsewhere-and, indeed, ainong nations.

II

\section{An Institution-Focused ApProach TO THE POWELL OPINION}

Let us now turn more explicitly to the impact of Bakke on equal protection theory. For all its vagueness, Bakke has set the agenda for future analysis of race-preference issues.

16. Even the opening lines of the Brennan group's Bakke opinion, after quoting the "all inen are created equal" line in the Declaration of Independence, refers to "equal opportunity for all regardless of race or color" as being "the promise of our principles." $98 \mathrm{~S}$. Ct. at 2767. See also Justice Powell's opinion on the "personal rights" basis of the fourteenth amendinent, $98 \mathrm{~S}$. Ct. at 2748 (citing Shelley v. Kraeıner, 334 U.S. 1, 22 (1948), and other cases).

Attempts to find a different "original meaning" for the fourteenth amendment have been severely challenged in R. BERGER, GOVERnMENT By Judiciary: THE TRANSFORMATION OF THE FOURTEENTH AMENDMENT (1977). My own recent perusal, for a book manuscript in preparation, of the 1866 origins of the fourteenth amendment and the question of the understanding of the tinues, accords with Berger's. The weight to be given the "original meaning" is of course a different question.

17. The fourteenth amendment (like the fifth aunendment) specifically protects "any person" against denial of equal protection or due process. Compare the language of the Equal Rights Amendment (ERA) which seems to abandon or at least obfuscate the convential constitutional focus on individuals rather than groups: "Equality of rights under the law shall not be denied or abridged by the United States or by any state on account of sex." Would it be easier to justify an overt sexual-preference quota under the ERA (based perhaps on a theory of compensating woinen for past restrictions of opportunity), than under the equal protection principles in the fifth and fourteenth amendments? 
Especially critical is the extent to which the fourteenth amendment's traditional focus on individual rights ${ }^{18}$ can be reshaped into-or replaced by-a group rights concept. ${ }^{19}$ The issue underlays the Powell and Brennan group opinions, especially the former, but remains unclear for at least two reasons. One is the fragility of the Powell position as a matter of power, as already mentioned. The second is Justice Powell's recognition, in the second half of his opinion, of "genuine diversity," 20 necessarily keyed in part to a group representation concept, as a legitimate objective for a state school to seek in its student body-that is, to achieve the "educational diversity valued by the First Amendment."21 (Justice Powell did not reach the question whether the state or federal government could command such an objective.)

How transferable is this academic diversity version of the group representation concept? How much can it be broadened? At what point does it become a concealed, but forbidden quota?

One key aspect to observe is that Justice Powell's diversity idea is based on an interest of the institution-that is, an enterprise interest in an enriched educational atmosphere-rather than on an interest held

18. J. Porter, Ethnic Pluralism in Canadian Perspective, in ETHNICITY: THEORY AND EXPERIENCE (N. Glazer \& D. Moynihan eds. 1975). Professor Porter sees a conflict between group rights theories and the idea of a modern society based on citizenship where the individual makes a claim as a citizen or in a status coinmon to all members.

19. One of the most ambitious, but ultimately unsuccessful, attempts to develop a group rights theory under the fourteenth amendinent is found in Fiss, Groups and the Equal Protection Clause, 5 PHILosophy AND PuB. AFF. 107 (1975). The essence of the special groupism argument is to deny that there are "natural forces." But unless a large amount of what occurs is simply taken as a given-including the elemental "chance factor" of being born to one parent rather than another, or imto a family with two children rather than ten-a regine of liberty becomes impossible. When Fiss says that "working with the concept of group" to develop a regime of preferential treatment is "messy," id. at 149, he barely hints at the dimension of the inherent danger.

By deflnition, groupism cannot be left to elective pohitics-i.e, to democracy-because majorities prefer themselves. Similarly, the products of group coalition politics would be unprincipled to those like Fiss who espouse reverse discrimination on a "disadvantaged group" principle. Id. at 157. Recourse therefore must be had to the courts to pick and choose among groups, id. at 156 , thus creating a startling role for the courts to identify and modify national priorities. Even assuming judicial wisdom, the tensions and financial costs resulting from redistributive judicial orders could push judicial credibility and acceptance to the breaking poimt.

Fiss admits that even if it is true that the equal protection clause, on the basis of historical evidence, could be shown to be intended to protect blacks, that still would not tell us "whether blacks were to be viewed as a group or as individuals," nor would it "say inuch about the intensity or degree of protection that is to be afforded." Id. at 173. The solution is to trust the judiciary. The judge "must become a natural lawyer out of default" and courts inust contribute to moldimg the "popular morality." Id. at 173.

20. Regents of the Univ. of Cal. v. Bakke, 98 S. Ct. at 2761.

21. Id. at 2762 . In an advisory comment on the elements of the perinissible academic diversity, Justice Powell pointed to the Harvard College admissions prograin where the judgment had been made that "if Harvard College is to continue to offer a first-rate education to its students, minority representation in the undergraduate student body cannot be ignored by the Committee on Admissions." $98 \mathrm{~S}$. Ct. at 2765 (Appendix to opinion of Powell, J.) (emphasis added). 
by the represented minority group. ${ }^{22}$ This seems to be Justice Powell's view, despite the fact that the represented groups are the immediate beneficiaries of the policy, and the proximate cause of the liypothesized enrichment.

Several implications flow from viewing Justice Powell's diversity idea as an institution-focused concept. If what Justice Powell has said is that it is legitimate under the fourteenth amendment for an enterprise to seek diversity, defined as some minority group representation relevant to the enterprise, even though some majority group members suffer a bit, then several possibilities not thought through by Justice Powell, perhaps not intended by Justice Powell, may follow.

First, if the Powell view is characterized as recognizing a legitimate enterprise interest (in the Davis case, a legitimate state enterprise interest), then Justice Powell is not creating an enforceable group right in the minority group selected by the enterprise for the beneflt. At most there would be a rule-of-reason type review of the policy chosen.

Second, although loose use of the diversity principle by many enterprises could close the gap between Justice Powell and the Brennan group in actual result, a most significant distinction in principle would remain. Under the Brennan group opinion, it would seem to be a short step from the proposition that Davis "voluntarily" may seek diversity ${ }^{23}$ to reınedy centuries of societal discrimmation, to the proposition that an aggrieved minority plaintiff can counpel Davis to have minority representation.

Recall that the Brennan group's point is not that admissions tests or employment tests themselves are unfair, even though blacks as a group often tend to score lower thian whites and hence are excluded inore often than whites when the test is an entry requirement. They call suclı results a "disparate racial impact." 24 Their point, rather, is that such "disparate racial impact" may be assumed to be the product of past discrimination by "society at large." 25 Simce society assumedly

22. After associating "academic freedom" with the first anendment, Justice Powell said: "The freedom of a university to make its own judginents as to education includes the selection of its student body." Id. at 2760 (emphasis added).

23. "Voluntarism" in higher education admissions and hiring and promotion practices is significantly qualified by duties to file and follow affirmative action plans containing specific goals and timetables for increasing the percentage of minority group inembers. The duties inay arise under HEW regulations anplifying Title VI of the 1964 Civil Rights Act, see, e.g., 45 C.F.R. $\$ 80.5 i$ (1977), or under Executive Order No. 11246, 3 C.F.R. 339 (1964-1965 Compilation), that imposed affirmative action obligations on government contractors without requiring prelininary judicial findings of intentional discrimination. See, e.g., the "agreeinents" negotiated by the HEW Office of Civil Rights with four universities (Ohio State, Purdue, Michigan, Wisconsin) as a condition of continued eligibility to receive inultinillion dollar contracts. CHRONICAL OF HigHER Educ., Jan. 16, 1978, at 16.

24. $98 \mathrm{~S}$. Ct. at 2789.

25. Id. 
has caused the lowered performance, society should pay for it.

Some of Justice Powell's sharpest comments, in his footnote 36, came in criticizing what he called the "unprecedented" breadth of the Brennan group's societal discrimination formulation. ${ }^{26}$ A majority of the Court has never yet defined so loosely the constitutional violation which is a precondition to race-conscious or race-preference corrective action. But the Brennan group lacked only one vote (although Justice Blackmun to be sure was a reluctant follower) ${ }^{27}$ If a majority were achieved for this societal discrimination concept, would this not only reverse Bakke, but also be a basis for making overt ethnic quotas mandatory by judicial order? Why not? To paraphrase Gertrude Stein's line about roses, discrimination is discrimination is discrimination, whether individual or societal, and where it exists it cries out for a remedy. School desegregation could also be materially affected because a societal discrimination concept seemingly would end the need to prove official discriminatory intent as a precondition of a racial balance order. ${ }^{28}$

By contrast, the Powell diversity formulation, viewed as an institution-based concept, for all its vagueness, does not seem to lead to an enforceable group right.

Third, if the Powell diversity concept is characterized as an enterprise interest rather than a group right.interest then it is less readily transferable to nonacademic areas. Consider, for example, einployment and the Weber v. Kaiser Aluminum and Chemical Corp. case now pending in the Supreme Court. ${ }^{29}$ There the enterprise interest gives rise to considerations not of broadened dialogue, but economy, efficiency, productivity, and the like-considerations tending to cut against the Davis-type modification of conventional admissions criteria, even if done on a less drastic basis.

Fourth, the resulting scope of congressional enforcement power would be quite different under the Powell diversity concept, thus cliaracterized as an enterprise improvement concept, than under the Brennan view. Under the Brennan group's societal discrimination concept, Congress would have broad power under section 5 of the fourteenth

26. Id. at 2751 n.36.

27. Justice Blackmun recorded his "earnest hope" that "affirmative action" programs could end "within a decade at most," but recognized that the "hope is a slim one." Id. at 2806.

28. Specifically, the Brennan formulation would seem to call into question cases like Village of Arlington Heights v. Metropolitan Hous. Dev. Corp., 492 U.S. 252 (1977), and Washington v. Davis, 426 U.S. 229 (1976), on the question of the plaintiffs burden of proving intentional discrimination in racial cases under the fourteenth amendment, and Pasadena Bd. of Educ. v. Spangler, 427 U.S. 424 (1977). Spangler indicated that absent proof of new discriminatory intent the fact of frcsh racial nonproportionality caused by demographic factors like white flight would not create judicial power to devise a new busing order.

29. 563 F.2d 216 (5th Cir. 1977), cert. granted, 47 U.S.L.W. 3401 (Dec. 11, 1978) (No. 78435). 
amendment to devise race-preference remedies, without logical limit as to stringency or duration. Under the Powell concept of diversity as a permissible pohicy for a quasi-autonoinous institution, section 5 would not be triggered unless Congress had the votes to make "findings" of past discrimination and continued effects. ${ }^{30}$

Justice Powell's approach seems to be to permit, but not compel, diversity policies in the cause of academic freedom. It would seem to follow that academic freedoin would permit some colleges to seek homogeneity if they had a rational basis for doing so. This could increase total societal diversity, even though particular institutions would remain hoinogeneous to serve a special function. ${ }^{31}$ Justice Powell did not discuss the point explicitly, but consider the case of religious colleges; or the black colleges that are worried about the Carter Administration's integration pohicies; ${ }^{32}$ or ethnic-centered enterprises in general.

30. See 98 S. Ct. at 2755 n.41 (citing Katzenbach v. Morgan, 384 U.S. 641 (1966)). It must be recognized that legislative findings are essentially political acts. However, they may become impregnable by judicial deference. In Katzenbach, indeed, the undergirding "legislative" findings were merely "hypothesized," 384 U.S. at 669 (Harlan, J. dissenting), in Justice Brennan's opinion for the Court. See, e.g., id. at 656 ("it is enough that we perceive a basis upon which Congress might predicate a judgment").

31. See Wilkinson, Black Colleges: The Right to Segregate, Wash. Post, Jan. 1, 1979, \& A, at 15, col. 1. See also reınarks of Professor Nathan Glazer at the Washington University symposium, supra note 3:

This is a multi-ethnic country, with a rich group life centered on religion, etlunicity, race. We expect these varied groups to establish institutions which are in some substan. tial degree exeinpt from universalisin in their practices, even though we bar them from practicing a crude racisin. Thus we expect a Lutheran college to be attractive to Lutherans, and few of us would be disturbed if it tried to seek out good Lutheran students. And this is not only because we give special license to religion. Even if it were Norwegian Lutheran, and tried to ensure a body of students of Norwegian Lutheran background with interest in that specific ethno-religious tradition, it would not bother us. We are also aware that inuch of the sinall business of this country runs on family lines, and beyond that on ethnic lines. The fact that an Italian restaurant prefers Italian employees would not be a cause of great concern, though our literal and narrowminded bureaucrats often find that hard to accept. But while our ethnic and religious subgroups properly maintain theunselves through associational and business ties, based in part on ethnicity and religion, we want our governınent, standing above all groups and ideally blind as justice is expected to be, to be universalistic in its practices in hiring and decisionmaking.

32. A series of stories in The Chronicle of Higher Education has dealt with the black colleges' dual concern about the impact of desegregation of state systems, primarily in the South, and about continued federal financial assistance in the wake of an HEW audit and a two-year General Accounting Office investigation focusing on allegations of fiscal mismanagement. Most of the 45 private black colleges rely on federal aid for 40-60\% of their annual budgets, Chronicle of Higher Educ., July 3, 1978, at 2, and the 34 traditionally black public colleges face an uncertain future under desegregation plans. Id., May 1, 1978, at 3. See also id., Nov. 13, 1978, at 12; id., June 26, 1978 , at 1. 


\section{III}

\section{ADDITIONAL IMPACTS OF $B A K K E$ ON CONSTITUTIONAL THEORY}

Moving on from the Powell diversity concept, reformulated as an institution-based concept, there are additional significant implications of Bakke for equal protection theory.

Bakke should trigger a long overdue refocusing of attention on the concept of actual discrimination ${ }^{33}$ and its proof, as Assistant Attorney General Drew Days has suggested. ${ }^{34} \mathrm{He}$ and I may differ on whether we can back away very much from proof of intent and still call it actual discrimination, but the matter inerits careful analysis. Logically, a more conscious focus on actual discrimination as the basis for race conscious or racially preferential orders could lead both to a more focused concept of the beneficiary group and clarification of the duration of the remedy in their behalf. We desperately need a better sense of these two kinds of limits.

A sharper focus on the concept of "right," and a more precise definition of the related "remedy," could have impact on the school desegregation cases. As long as the Powell position holds, cases like Pasadena Board of Education v. Spangler ${ }^{35}$ are strengthened. In Spangler, the Court held that once a culpable school system has honored its duty under Swann v. Charlotte-Mecklenburg Board of Education" ${ }^{36}$ to devise a plan "to achieve the greatest possible degree of

33. At the same time, it will be important to be alert to the hidden agenda underlying renewed scrutiny of familiar terms and to outright attempts to turn conventional definitions inside out. See, e.g., Brest, Foreword: In Defense of the Antidiscrimination Principle, 90 HARv. L. Rev. 1 (1976). Although starting out in conventional colorblind terms, the antidiscrimination concept is quickly reduced to race-dependent decisions that disadvantage meinbers of minority groups. Without being explicitly articulated, it is a group approach to equal protection, and operates to leave members of majority groups outside the range of the protective principle. Under the Brest recasting of the antidiscrimination principle, even the kind of outright quota that the Supreme Court subsequently invalidated in Bakke would pass muster. Allan Bakke, although excluded, would not suffer "stigmatic harm" personally, and the white majority as a group would not be likely to suffer "cumulative harms." Id. at 17.

34. See note 3 supra. Assistant Attorney General Days seemed to signal a new Carter Administration policy of focusing on the concept of discrimination and the manner of its proof. As he stated:

At some point we have to come face to face with the fact that we have constitutional principles that are at odds and that conflict cannot be fudged and the solution ultimately will have to come from an identification of the truly legal and constitutional bases for what we are domg. ... It seems to me that further litigation or administrative action has to emphasize the extent to which discrimmation actually exists. . . . [I]f we don't [so focus] we're really on the slippery slope and ... we will essentially be thrown into the political process in the worst sense of the word-a dog fight over scarce resources that cannot . . . bring us to the point of being colorblind in a society . . . truly open to talent. Id. On proof, he suggested further experimentation with rebuttable presumptions of discriminatory intent based on a showing of various kinds of racial nonproportionality. Id.

35. 427 U.S. 424 (1976).

36. 402 U.S. 1 (1971). 
actual desegregation," 37 that ends the matter. There is no duty to revise the plan to respond to new racial nonproportionality as people move, unless there is proof of renewed actual discrimination by the governmental authorities. There is no constitutional right to integration or racial balance - that is, no constitutional right to group recognition, as such. ${ }^{38}$

One idea that does seem to be undermined by the Powell compromise is that no constitutional problem arises when the majority chooses to sacrifice some of its own in order to benefit a minority group member. We must not forget that the Bakke case was brought by a white, whose admissions test percentiles averaged ninety, asserting a personal right not to be subjected to a white imposed pohicy whereby some ineinbers of three selected minority groups ${ }^{39}$ would be admitted in his place even though their percentiles averaged thirty.

The Brennan group did not view this claim as triggering the full strict scrutiny equal protection test because, although Allan Bakke was injured, the quota classification did not stigmatize whites, as a class, as inferior. Characterizing Allan Bakke's claim, the Brennan group said: "But no fundamental right is involved here. . . . Nor do whites as a class have any of the 'traditional indicia of suspectness. . . ." 40 They did think, however, that the matter was important enough to require the state to show that the quota served "important governmental objectives" and was "substantially related" to achieving those "objectives";,41 in other words, just the so-called "middle level" or "strong rational basis" test for whites. ${ }^{42}$ The Justices, in effect, would have held that equal treatment for whites is not a "fundamental right" unless the white majority is being threatened. That sounds bald. But it must be reınembered that the idea of strict judicial scrutiny of some kinds of governmental policies traces back to a footnote in Justice Stone's opinion in United States v. Carolene Products Co., ${ }^{43}$ a 1938 nonracial case, in which he linked it to the problein of "discrete and insular minorities." According to the Breiman group, nonıninorities can look to the

37. Id. at 26.

38. As an aside, consider the tension between Spangler and Milliken v. Bradley, 433 U.S. 267 (1977) (Milliken II). Does Milliken II ensure an open-ended period of court supervised remedial instruction until racial balance on standardized tests is achieved? Bakke does not speak to that tension.

39. See note 6 and accompanying text supra.

40. $98 \mathrm{~S}$. Ct. at 2783.

41. Id. at 2784 .

42. See Dixon, The Supreme Court and Equality: Legislative Classifications, Desegregation and Reverse Discrimination, 62 CORNELL L. REv. 494, 525 (1977).

43. 304 U.S. 144 (1938).

44. Id. at 152 n.4. 
"majoritarian political process"45 for protection and need only modest judicial protection. Said rapidly all this may have some plausibility. Taken to its logical extreme, however, does it amount to saying that civil rights have little or no place in an ethnically homogeneous society, black or white?

Justice Powell rejected this idca that a majority should have some leeway in sacrificmg one of its own. He observed quite realistically that the American white majority is a collection of minorities; he saw "no principled basis for deciding which groups would merit "heightened judicial solicitude' and which would not."46 For all of Justice Powell's later caveats about the permissibility of reasonable diversity policies, this central personal right aspect of Bakke is a significant part of the legacy of the case. And it may be one that will not be changed easily, in the hight of the public mood, by future courts.

We must also bear in mind, in connection with the group rights question in Bakke, the other provocative group rights case, United Jewish Organizations $v$. Carey. ${ }^{47}$ I will offer suggestively only this much. Legislative representation, unlike voting per se, is in essence a group interest concept. ${ }^{48}$ It is perhaps the one true home of the group interest concept. The aim is fair and effective representation for the major contendimg interests, worked out awkwardly through a legislative district system, because we fear the instability of a formal proportional representation system of election. The reapportionment concepts have recently been considerably confused by developments under the Voting Rights Act, ${ }^{49}$ but I lay that aside. In United Jewish Organizations, some of the justices were ready to transcend the Voting Rights Act and to decide on constitutional grounds that it was permissible to carve up the Hasidic Jewish community in order to create supposedly safe black districts with a sixty-five percent resident plurality. ${ }^{50}$ I strongly question the propriety of saymg that the Hasidic Jews had no constitutional case because whites as a whole had adequate representation, if one looked at the totality of the legislative districts in Brooklyn; and not just at the "safe" black ones among which the Jewish plaintiffs were allocated.

45. 98 S. Ct. at 2783 (quoting United States v. Carolene Prods. Co., 304 U.S. 144, 152 n.4 (1938)).

46. Id. at 2751 .

47. 430 U.S. 144 (1977).

48. See R. Dixon, Democratic Representation: Reapportionment in Law and Polmincs 3-24 (1968); Casper, Apportionment and the Right to Vote: Standards of Judicial Scrutiny, 1973 SuP. Cr. Rev. 1.

49. 42 U.S.C. $\$ 1973$ (1976). See Wise v. Lipscomb, 98 S. Ct. 2493 (1978), and cases cited therein. See also Kirksey v. Bd. of Súpervisors, 554 F.2d 139 (5th Cir.) (en banc), cert. denied, 434 U.S. 968 (1977); Note, Group Representation and Race Conscious Apportionment: The Roles of States and the Federal Courts, 91 HARv. L. Rev. 1847 (1978).

50. United Jewish Organizations, Inc. v. Carey, 430 U.S. 144, 166 (1977) (White, J., with Rehnquist, Stevens, JJ., concurring). 
This again is the idea of majority sacrifice-those sacrificed being taken care of vicariously by representation of other whites. I raise this question: Does Justice Powell's opinion in Bakke intimate that even in the legislative representation area, which concededly is the true home of group rights thinking, there may be constitutional limits to the permissible range of the vicarious representation principle?

I should add at this point that the principle of Gaffney $v$. Cummings, ${ }^{51}$ cited in United Jewish Organizations ${ }^{52}$ is different. In that case, which it was iny lot to brief and argue in the Supreme Court, the Court-in reviewing Connecticut's plan of extreinely equal legislative districts-upheld the permissibility of the state's concurrently considering political realities in its attempt to devise a set of districts that would be fair overall to each of the major political parties. After all, the preceding "one inan-one vote" set of districts had produced a minoritycontrolled legislature. There is a significant difference between seeking political fairness in conventional party terms, as in Gaffney, and delving into the ethnic coinposition of parties, as in United Jewish Organizations.

\section{IV}

\section{RELATION TO THE STATUTORY AND EXECUTIVE ORDER CASES}

No treatment of Bakke would be coinplete without a more explicit reference than $I$ have yet made to its possible impact (or vice versa) on the statutory and executive order cases, under the Civil Rights Act of $1964^{53}$ and Executive Order 11246, as amended, setting goals and timetables for government contractors. ${ }^{54}$ Without explicit congressional or Supreme Court approval (and I think the belatedness of Supreme Court review here inay be significant), the civil rights agencies and the lower federal courts have developed a simple proof formula. That formula unabashedly uses gross population figures. Racial nonproportionality is easily shown. ${ }^{55} \mathrm{~A}$ judicial order commanding some form of

51. 412 U.S. 735 (1973).

52. United Jewish Organizations, Inc. v. Carey, 430 U.S. 144, 167-68 (1977).

53. 42 U.S.C. § 2000d-e, h-2 (1976) (Titles VI, VII, IX).

54. 30 Fed. Reg. 12,319 (1965), 3 C.F.R. 339 (1964-1965 Compilation), as amended by Exec. Order No. 11375, 32 Fed. Reg. 14,303 (1967), superseded in part by Exec. Order No. 11478, 34 Fed. Reg. 12,985 (1969), reprinted in 42 U.S.C. $\$ 2000 \mathrm{e}$ note. For provisions regarding the establishment of goals and timetables, see 41 C.F.R. $\S$ 60-2.12 (1978) (original version at $36 \mathrm{Fed}$. Reg. 23,154 (1971)). See Contractors Ass'n of E. Pa. v. Secretary of Labor, 442 F.2d 159 (3d Cir. 1971), cert. denied, 404 U.S. 854 (1971).

55. See, e.g., the area population racial ratios used as the basis for the nominally "voluntary" agreement (one-for-one admission, black and white, to on-the-job training program) at issue in Weber v. Kaiser Aluminum \& Chemical Corp., 563 F.2d 216, 222-23 (5th Cir. 1977), cert. granted, 47 U.S.L.W. 3401 (Dec. 11, 1978) (No. 78-435), and cases cited therein on judicially imposed quota remedies. Id. at 221-22. 
racially preferential hiring or admission procedure follows as a matter of course because the defendant is in the almost impossible situation of proving a negative.

Last November, however, in Board of Trustees of Keene State College v. Sweeney, ${ }^{56}$ the Supreme Court seems to have signalled more stringency. The Court insisted again, as it had in Furnco Construction Corp. v. Walters, ${ }^{57}$ that to rebut a prima facie case based on such statistical proof it is sufficient for an employer to "articulate some legitimate nondiscrimmatory reason for the employee's rejection." 58 . The employer is not required to prove absence of discrimination. Both Keene State and Furnco have roots im the Supreme Court's somewhat analogous warning to the lower federal courts in 1973 in McDonnell Douglas Corp. v. Green. ${ }^{59}$

What the lower courts had been doing up until these recent Supreme Court cases was to lose sight of the right-reinedy distinction. Indeed, they had coalesced the two, so that just as little more than a showing of ethnic nonproportionality in gross population terms had been needed to trigger an administrative or judicial order for quotas or race preferences, there also was no logical stopping point short of coinplete ethnic proportionahity. So, although it may be true that many in the federal civil rights agencies, or President Carter, would recoil at the idea of creating a group-rights based, ethnically proportionalized soci-

In its Petition for Certiorari in Weber, the United States indirectly recognized the presumptively nonvoluntary nature of employer agreements in this field: "The affirmative action obligations imposed on Kaiser and other federal contractors by Executive Order 11246 further supports the lawfulness of voluntary affirmative action programs adopted by agreement between unions and employers." Id. at 15 (emphasis added).

A recent example of executive agency use of racial nonproportionality as the basis for quotatype policies is the Uniform Guidelines on Employee Selection Procedures, modifying traditional merit system selection practices for federal government employment. The guidelines prohibit use of any selection procedure (unless verified by a difficult process of validation) which has an adverse impact on hiring of blacks, American Indians, Asians, Hispanics, or whites. Adverse impact is defined as a "selection rate for any race, sex, or ethnic group which is less than four-fifths (4/5) (or eighty percent) of the rate for the group with the highest rate." 43 Fed. Reg. 38,297 (1978).

Quaere, whether in operation this new regulation will eliminate use of objective tests such as PACE (Professional and Administrative Career Examination) for entry-level professional civil service positions, insofar as minorities in general score lower than whites on general aptitude tests as indicat $t$ d by the experience record under the Law School Admission Test and the Medical College Aptitude Test. See, e.g., comment of Mr. Justice Brennan: "Moreover, while race is positively correlated with differences in GPA and MCAT scores, economic disadvantage is not. Thus, it appears that economically disadvantaged whites do not score less well than economically advantaged whites, while economically advantaged blacks score less well than do disadvantaged whites." 98 S. Ct. 2733, 2793 (Brennan, J., dissenting).

56. 99 S. Ct. 295 (1978).

57. Furnco Constr. Corp. v. Waters, 98 S. Ct. 2943 (1978).

58. 99 S. Ct. 295, 295 (1978) (quoting Furnco Constr. Co. v. Waters, 98 S. Ct. 2943, 2950 (1978)).

59. 411 U.S. 792 (1973). 
ety, the loose, open-ended formulae that they have developed and used to win cases until 1978 point straight in that direction. Bakke, Furnco, and Keene State seem to reinforce each other, and may require a fresh look at this simple statistical proof formula.

I doubt that Congress has the desire or the votes to reverse this Supreme Court strimgency. After all, the Supreme Court's rulings more clearly reflect the language of the Civil Rights Act than do the actions of the civil rights agencies and the lower federal courts. And even if the votes were available, there is the question of power. I do not read the power of Congress even under section 5 of the fourteenth annendment in quite such limitless fashion as soine do. To ine, Katzenbach $v$. Morgan $^{60}$ was an aberration, as Alexander Bickel characterized it, ${ }^{61}$ partially inodified rather than fully supported by Oregon $\nu$. Mitchell. ${ }^{62}$ But that is another story. Of course, if I ain wrong on all this, then all cases might become statutory cases, under clarified statutes, and we would move closer to the political "dog fight" over ethnic shares of scarce resources that Assistant Attorney General Drew Days, in his Washington University remarks, indicated he fears as inuch as I do.

\section{CONCLUSION}

In conclusion, the choices before us are rigorous and no course guarantees success. The easy targets are gone. Everyone seems to agree that the ultimate goal is a racially neutral society. Yet even under the Powell coinpromise, if it is loosely interpreted and policed, we may be embarked upon an endless round of adjusted and readjusted group preferences.

It has been suggested, notably in Justice Marshall's poignant opinion in Bakke, ${ }^{63}$ that the problein of the contest by many groups for ethnic shares under a broad societal discrimination idea could be avoided if reparations and preferences are confined to blacks, to end presumably when blacks as a group no longer have generalized disadvantages. Laying aside the points that it is too late in the day for such a single group approach and that the original understanding of the Civil War amendments does not support a reparations right, there are other problems with the reparations concept.

It conflicts with the basic western concept of equal citizenship and equahity of opportunity to seek excellence and it creates serious standards problenis, as in Bakke. There is strong popular support in the

60. 384 U.S. 641 (1966).

61. Bickel, The Voting Rights Cases, 1966 SuP. CT. Rev. 79, 102.

62. 400 U.S. 112 (1970). See Cohen, Congressional Power to Interpret Due Process and Equal Protection, 27 Stan. L. Rev. 603 (1975).

63. 98 S. Ct. at 2805. See also Calabresi, Bakke: Lost Candor, N.Y. Times, July 6, 1978, § 1, at 19 , cols. $1-4$. 
public opinion polls for catchup programs for which all pay, but strong resistance to suspending conventional standards. ${ }^{64}$ A small-scale reparations program would have little impact on racial ratios.

A large-scale reparations program would have a major impact on innocent whites, especially, as William Van Alstyne has pointed out, "on otherwise margmal white apphicants, i.e., those from circumstances least profiting from the antecedent racism in America and among the least able to pay that debt." ${ }^{65}$ Further, as Thomas Sowell has pointed out, use of gross population figures as the quota base would increase individual unfairness. Among ethnic groups, the average age of Mexican Americans and Puerto Ricans is under twenty; the average age of Jewish Americans is over forty. ${ }^{66}$

The answer to the alternative premise, mentioned by Erwin Griswold and Nathan Glazer at the Washington University symposium, that reverse discrimination is essentially a philosophical and political problem, is that the function of law, specifically constitutional law, is to protect individuals, as individuals, against the destructive or discriminatory hand of the state. And that protection is given even when the oppressive action is siniply a shortcut to a perceived social good.

More is at stake than group proportions. Personal dignity also is at stake in the Bakke situation. It cannot be avoided by the ploy of creatimg soine special definition of a nonconsitutional concept called "stigma," and saying to an Allan Bakke: "Relax. We know we demeaned your long effort by putting a C-plus, 30th percentile student above your B-plus, 90th percentile record. But we didn't stigmatize you by your whiteness, because we let so many other whites in. Go, bask in their reflected glory." Bakke might well respond in a word: "Chutzpah!" And so might the Brooklyn Hasidic Jews in United Jewish Organizations.

To commit personal rights to the logrolling of legislative majority coahtions in our current fragmented interest group politics may be quite democratic, to be sure. Congress may be able to create, or more likely HEW and EEOC and the Civil Rights Division in Justice may be able to create and keep finely tuned, a proportional representation society. But then all kinds of embarrassing questions are certain to be raised because when one's rights depend on one's group, the size of the group must be monitored closely. For example, on December 20, 1978, Congressman James H. Scheuer's House Select Committee on Popula-

64. Lipset and Schneider, The Bakke Case: How Would It Be Decided at the Bar of Public Opinion, PuBlic OpINION, March/April 1978, at 13.

65. Van Alstyne, A Preliminary Review of the Bakke Case, 64 AM. A OF U. Professors Bull. 286, 296 (1978).

66. Sowell, Racial Quotas Achieve Nothing-At Great Cost, Wash. Post, June 18, 1978, § B, at 1, col. 1 . 
tion cited "potentially explosive" levels of immigration, and recommended that the United States border with Mexico be sealed. ${ }^{67}$ Will some future report of the Committee raise the question of population control at home?

The function of constitutional law is not to abdicate to politics, but to force majorities to deal fairly even with their own kind. The fourteenth amendment does not read: "No person shall be denied the equal protection of the laws, except by members of his own group."

The Jackie Robinsons and Albert Einsteins were pioneers for tolerance. But most certainly, a general pohcy of keying rewards to class or group jeopardizes respect and tolerance between class and class, group and group, family and family, person and person.

I find it hard to beheve that a major abandonment of our traditional einphasis on individual rights is good in the long run; and if we abandon it in the short run I see no agreed turnaround point. We are becoming equahity pilgrims a long ways from justice, and it is not fully clear whether we are moving toward or away from justice.

67. Wash. Post, Dec. 21, 1978, § A, at 1, col. 1. 